\title{
MUC16 Ectodomain Antigen Positive
}

National Cancer Institute

\section{Source}

National Cancer Institute. MUC16 Ectodomain Antigen Positive. NCI Thesaurus. Code C148381

An indication that a soluble form of the extracellular domain of the mucin-16 protein has been detected in a sample. This is a marker for intramembrane cleavage of mucin-16. 